\title{
ANNA CZABANOWSKA-WRÓBEL
}

\section{Ogień życia. \\ Wiersz Adama Zagajewskiego \\ O mojej matce}

Ogien życia to tytuł jednego $\mathrm{z}$ ostatnich, krótkich szkiców Richarda Rorty'ego, skąd pochodzą słowa „nigdy nie będziemy w kontakcie z czymś większym niż my sami" '. Stanowią one motto jednego z wierszy tomu Niewidzialna ręka zatytułowanego Czerwiec w Sienie. Pod koniec życia Rorty z całą mocą deklaruje, że to nie filozofia, którą się zajmował, i nie religia, ale poezja stała się dla niego najcenniejsza: „Znalazłem pocieszenie w tych spokojnych meandrach i migocących żarach” - mówi Rorty. „Podejrzewam, że porównywalnego efektu nie mogłaby osiągnąc proza" ${ }^{2}$. Filozof wskazuje na rolę kondensacji, zgęszczenia w mowie poetyckiej. Przypomnijmy, że głęboki ślad takiego jej rozumienia zachował się w języku niemieckim - „Dichtung” ma związek z czasownikiem „dichten” i ten źródłowy sens „zgęszczania” w nim przetrwał. Sam Zagajewski formułuje w Lekkiej przesadzie następującą definicję, która będzie tu potrzebna: „Poezja nie diagnozuje, tylko ustanawia. Próbuje ustanowić ale może ustanowić tylko to, co jest" ${ }^{3}$. Można więc przyjąć, że wiersz ustanawia i ogłasza to, co było - bez pięknego kłamstwa, bez żadnej, nawet lekkiej, przesady.

Wiersz $O$ mojej matce ${ }^{4}$ to utwór w dorobku Zagajewskiego ważny, może nawet przełomowy; to, jak dotychczas, jedna z najbardziej osobistych wypowiedzi lirycznych poety. Czytany na tle całej jego twórczości pozwala lepiej zobaczyć zmiany, jakie w niej wciąż następują, ale także, paradoksalnie, odkryć ciągłość wątków obecnych od samego początku, nawet we wczesnym, nowofalowym okresie, w którym trudno na pierwszy rzut oka

\footnotetext{
I R. Rorty, Ogień życia, przeł. A. Żychliński, „Odra” 2008, nr 6, s. 46.

2 Ibidem, s.47.

3 A. Zagajewski, Lekka przesada, Kraków 2011, s. 230.

4 Wiersz O mojej matce zamieszczony został na końcu artykułu.
} 
pod warstwą pełnych energii metafor i politycznych treści odkryć to, co jednostkowe i intymne. Z wiersza Lotnisko w Amsterdamie dowiadujemy się, że to z matką związane są słowa „listki mięty miały łagodzić migrenę...” ". Jeśli podążyć śladem tego cytatu, okaże się, że już we wczesnym wierszu Cukier pojawił się ten właśnie motyw:

Dzieciństwo skrytka duszna

od wilgotnych pocałunków i zapachu mięty ${ }^{6}$

Bardziej zrozumiałe staje się także, dlaczego poeta nazywa siebie „dzieckiem mięty” 7 w wierszu Autoportret.

Gdyby natomiast zrezygnować z wybranej przez mnie perspektywy, jaką jest badanie wyłącznie twórczości samego Zagajewskiego, wiersz mógłby zostać wpisany w bogatą w poezji polskiej przełomu XX i XXI wieku - a wywodzącą się jeszcze od Kochanowskiego - tradycję utworów przywołujących pamięć zmarłej matki. Jednak trzeba podkreślić, że chodzi tu o relację dziecko-matka w wariancie syn-matka, bo temat matki i cór$\mathrm{ki}$, tak istotny dla twórczości kobiet przez cały wiek XX, ma na początku XXI wieku realizacje odmienne, co czasami znaczy bardziej dramatyczne. Ich kulminację stanowi Utwór o Matce i Ojczyźnie Bożeny Keff. Scenariusz oddzielania się od matki jest $\mathrm{w}$ przypadku kobiet $\mathrm{w}$ naszym kręgu kulturowym na tyle inny niż ten przewidziany dla mężczyzn, że (bez odwołań do języka psychologii) można stwierdzić, iż literatura w pełni tę różnicę odzwierciedla.

Artyści-mężczyźni zazwyczaj nie ujawniają wprost, że z ich perspektywy istotne jest nie to, jaka matka była obiektywnie, ale jaka była dla nich, że przechowali w głębinach twórczej wyobraźni pokłady pierwotnego, dziecięcego egoizmu. Tytuł O mojej matce wskazuje, że Adam Zagajewski jest w pełni świadomy tego, że mówi o jednej z najbliższych mu osób $\mathrm{z}$ całkowicie subiektywnej perspektywy. Dzięki owej świadomości podejmuje próbę wyraźnego oddzielenia pytań o jej osobowość od tego, jaką rolę odgrywała w jego życiu. Jednoznaczny tytuł z zaimkiem dzierżawczym dowodzi też, że podmiot tego wiersza to nie jest już persona Zagajewskiego $\mathrm{z}$ lat osiemdziesiątych, wydestylowana z tego, co prywatne i osobiste, że jest on ściśle i bezpośrednio związany z samym autorem. Dlatego wolno tu także interpreta-

Idem, Wiersze wybrane, Kraków 2010, s. 167.

Idem, Komunikat, Kraków 1972, s. 27.

Idem, Wiersze wybrane, s. 208. 
torowi zadawać pytania o Ludwikę z Turskich Zagajewską, znaną $\mathrm{z}$ esejów wspomnieniowych poety.

Konstrukcja wiersza wspiera się na ramie powtórzenia z pierwszego i ostatniego wersu, nie ma jednak zamkniętego charakteru ze względu na zastosowanie w ostatnim wersie retorycznego umilknięcia (aposiopesis), znanego starożytnym mowom żałobnym dramatycznego przerwania wypowiedzi. To jedynie pozorne zamilknięcie, i to nie tylko dlatego, że Zagajewski dalej pisze o matce. Podczas wieczoru poezji w Poznaniu w maju 2011 roku czytał kolejne wiersze z powstającego właśnie cyklu. Retoryczny gest zamilknięcia jest $\mathrm{w}$ istocie otwarciem dalszej możliwości mówienia.

Cały utwór, zamknięty klamrą sformułowań: „nie umiałbym nic powiedzieć” „i wciąż nie umiem”, zawiera szereg powiązanych ze sobą spójnikiem „i” zdań, co sprawia wrażenie, jakby monolog podmiotu był wypowiadany na jednym oddechu. Zastosowany tu polisyndeton daje efekt anafory i kolejne „jak” otwierają małe, niewyodrębnione graficznie całostki. Wyliczenia nie są monotonne, o czym decyduje zmienny rytm - z niewielkimi odmianami przeplatają się słowa: „jak ona” „i jak ja”. Napięcie miedzy powracającym, powtarzającym się zestawieniem: „jak ona...” - „jak ja...” zatarte jest częściowo przez stylizację na swobodną wypowiedź, której tempo podyktowane jest przez rytm pamięci. Monolog stanowi ciąg luźno powiązanych ze sobą przypomnień, nierespektujących ani chronologii, ani hierarchii wspominanych wydarzeń. Użyte tu figury retoryczne mowy żałobnej nakazują pamiętać o elegii, choć utwór nie jest do końca elegią żałobną ${ }^{8}$. Był nią poświęcony matce, powstały w niedługi czas po jej stracie utwór Lotnisko w Amsterdamie, wiersz zawierający odniesienia do rzeczywistej sytuacji powrotu do Polski ze Stanów Zjednoczonych $\mathrm{z}$ międzylądowaniem na wielkim, pozbawionym i pozbawiającym prywatności europejskim lotnisku. Elegia żałobna Lotnisko w Amsterdamie opatrzona została jednoznacznymi słowami „Pamięci mojej Matki”:

Twój pogrzeb może mógłby się odbyć tutaj - tyle nieuwagi, uciekający thum, dobre miejsce dla nieobecności [...]

Żegnałem cię na lotnisku, w dolinie pośpiechu, tam, gdzie łzy są na sprzedaż 9 .

${ }^{8}$ Por. A. Legeżyńska, Gest pożegnania. Szkice o poetyckiej śrwiadomości elegijno-ironicznej, Poznań 1999.

9 A. Zagajewski, Wiersze wybrane, s. 167. 
Już w tym utworze matka charakteryzowana była poprzez kontrast $\mathrm{z}$ resztą rodziny:

$\mathrm{W}$ naszej ascetycznej rodzinie byłaś mistrzynią ekspresji... ${ }^{\text {To }}$

- ta melancholijna i autoironiczna aura powróci w wierszu O mojej matce.

Klamra, jaką tworzą pierwszy i ostatni wers utworu, otacza kolejne całostki. Można je porównać do oświetlonych okien, do których kolejno zagląda podmiot, sięgając zarazem w swoją przeszłość.

Pierwsze okno przywołuje wypowiedź znamienną dla wielu matek, powtarzaną przez te $\mathrm{z}$ nich, które $\mathrm{w}$ przypadku dziecięcych przewinień czuły się osobiście zranione: „będziesz kiedyś żałował, gdy mnie już nie będzie”. W podtekście tej powtarzanej frazy jest niewypowiedziana skarga na nieokazywanie przezdziecko uczuć, zależnie od sytuacji, skruchy albo czułości, w stopniu oczekiwanym przez matkę. Zdanie to ma w zamierzeniu wywołać poczucie winy, ale odbija się od dziecięcego (i utrwalonego na długo) upartego przekonania o nieśmiertelności matki, całkowitego odsunięcia od siebie myśli o możliwości jej utraty. Ona sama odsłania się tu jako skłonna do pewnej przesady, ,,egzageracji”, jak powiedziałby ktoś ze starszego od niej pokolenia.

Drugie okno ukazuje jej ciekawość i niecierpliwość w geście zaglądania na koniec czytanej książki. Ten przypadkowy zapamiętany szczegół nie zostaje skomentowany w żaden sposób, ale może zostać zrozumiany także i tak: matka jest ciekawa, „co będzie dalej”, jak się potoczą się losy jej dzieci i jak skończy się powieść jej życia. Znaczenie to, naturalne w tym miejscu, zostało osłabione przez epitet „modną” - sugerujący kierowanie się przez matkę aktualnymi gustami i pragnienie nadążania za tym, co dzieje się w kulturze.

Trzecie okno pozwala zobaczyć kuchnię, w której matka pozwoliła się zamknąć, chociaż tego nie akceptowała, paradoksalnie stając się zakładniczką dawnego świata, który odszedł, a który chciała ocalić. Wyemancypować się od obowiązków mogłaby tylko „przechodząc na stronę wroga”, stając po stronie narzuconej po wojnie ideologii. W przestrzeni, której nie wybrała, czuje się źle, nie u siebie, uważając (słusznie), że jest dla niej, na planie życia rodzinnego, kolejnym miejscem wygnania i powojennej degradacji - deklasacji: 
jak w kuchni, uważając, że to nie jest dla niej

odpowiednie miejsce, przyrządza niedzielną kawę,

W domowej kuchni mogłaby ostatecznie parzyć kawę, ale nie przygotowywać upokarzające dla niej „dorsze”, wstydliwe choćby przez to, że uważane po wojnie za namiastkę prawdziwego mięsnego dania. W wierszu synonimem ówczesnej prozy życia jest właśnie podkreślony kursywą „dorsz” , dobrze znany $\mathrm{z}$ trawestacji sloganu.

Czwarte i piąte „jak...”, wypowiadane z pełną czułości ironią, która płynnie przechodzi w autoironię, pozwalają zrozumieć, jak matka prezentowała się dla innych, na zewnątrz, ukryta za źle przylegającą maską, ukrywająca, jak można się domyślać, nadwrażliwość i niedostosowanie do raniącej rzeczywistości.

jak czeka na przyjście gości i patrzy w lustro, robiąc tę minę, która skutecznie chroniła ją prze zobaczeniem siebie naprawdę (co, zdaje się, odziedziczyłem po niej, jak i kilka innych słabości)

Potwierdzenie istnienia pojawia się w odbiciu w lustrze, a także w oczach innych ludzi. Niepewność epistemologiczna rodzi się, gdy pozór zastępuje rzeczywistość. Brak dostępu do siebie, nierozpoznawanie się w odbiciu, to temat, który $\mathrm{w}$ XX wieku obrósł bogatymi znaczeniami filozoficznymi ${ }^{\mathrm{ir}}$.

Szósty fragment zaczyna się od odwrócenia kolejności wspominania: ,jak ja jej niemądrze dokuczałem” - to wyznanie win wobec zmarłej, oskarżenie się z zaniedbań. Wyznanie dotyczy nie infernalnego zła, ale niegroźnego żartu, lekkiej złośliwości, pod którą kryło się lekceważenie i niedocenienie. Matka, skarżąc się na kłopoty ze słuchem, nie powinna, z obawy o śmieszność, porównywać się do wielkiego artysty. Młody Zagajewski skorzystał z tematu głuchnącego kompozytora na swój sposób, pisząc wiersz Późny Beethoven.

Siódme okno mieści się w topice antycznego trenu za sprawą pochwały osoby zmarkej (laudatio). Podmiot wskazuje na postawę stanowiącą kwintesencję macierzyńskiej bezwarunkowej miłości i powraca od jednostkowego szczegółu do tego, co ogólne. Wielu dorosłych ma to szczęście, że może wspominać: „jak wszystko mi wybaczała". Taka postawa matki nigdy nie może

II Barbara Sienkiewicz w wierszach o odbiciu w lustrze Kazimierza Przerwy-Tetmajera i Leopolda Staffa odnajduje początki nowoczesnej refleksji dotyczącej samopoznania. B. Sienkiewicz, Poznawanie i nazywanie. Refleksja cywilizacyjna i epistemologiczna w polskiej poezji modernistycznej, Kraków 2007. 
zostać $\mathrm{w}$ pełni odpłacona, niczym zrównoważona. Po stronie podmiotu przeciwwagę stanowi na poły bezradne (wzmocnione przez „naiwną”, podobną do dziecięcej narracji konstrukcję składniową): „i jak ja to pamiętam” - tu dochodzi również do głosu opłakiwanie straty (comploratio).

Ósma część wiersza stanowi wspomnienie powrotu do kraju na pogrzeb po nagłej śmierci matki. Brak pocieszenia (consolatio). Dziewiąta, zamykająca część powraca do początku i przygotowuje zakończenie całości utworu. Droga do wspomnień została otwarta.

Matka w poezji polskiej, od Kochanowskiego po Tkaczyszyna-Dyckiego i dalej, to temat-węzeł, który łączy znaczenia biograficzne i symboliczne ${ }^{\text {I2 }}$. Spośród wielości ujęć dla Zagajewskiego ważne jest to z poezji Miłosza i Różewicza, a także bliskiego mu Herberta, u którego obraz matki jest bardziej nieoczywisty.

Matka u Miłosza, w wierszach i wypowiedziach wspomnieniowych (przejmująca Elegia) - to wyrazista i mocna figura. W poemacie Grób matkiz tomu Światto dzienne(1953) jest przede wszystkim gwarantką ładu moralnego, strażniczką stałości tego, co trwałe w nietrwałym świecie i opiekunką (już po swojej śmierci, na mickiewiczowski sposób) powołania syna-poety. Klasycystyczne frazy zamykające poemat głoszą to bez żadnych zwątpień, z patosem:

Punkt nieruchomy, co dziejom na przekór

Na złe i dobre dzieli to, co płynne,

Pomóż mi, matko, umocnić w człowieku,

Ty, co znasz moje przysięgi dziecinne,

Spraw, niech mojego nie składam ciężaru.

Niech wiatr od Wisły biegnie oceanem,

Żeś chciała życia udzielić mi daru,

Bądź pozdrowiona w imię Boga. Amen³.

Ostatnie zacy towane tu słowa zawierają nie tylko sakralną formułę zamknięcia i potwierdzenia - niech tak się stanie, „amen” - ale mają przede wszystkim charakter dziękczynnego błogosławieństwa w czystej postaci takiej formuły językowej, w której przywołuje się Moc wyższą niż ludzka po to, by owe błogosławieństwo zostało spełnione. Świadomie anachroniczny stylizo-

I2 Por. A. Czyżak, Matkiodchodza. Wariacje 2009, „Poznańskie Studia Polonistyczne” 18 (38), 2011, s. 163-173; G. Borkowska, Matki (nie) odchodza, w: Redzinna Europa. Pięć minut póżniej, red. A. Kałuża i G. Jankowicz, Kraków 2011.

I3 Cz. Miłosz, Wiersze, t. 2, Kraków 2002, s. 66. 
wany charakter poematu Miłosza pogłębiają słowa zakorzenione w chrześcijańskiej formuje zwiastowania „bądź pozdrowiona...”, najściślej wiążące się właśnie (choćby to zabrzmiało jak tautologia) z macierzyństwem matki, z tym że stając się matką, przekazała bezcenny dar, jakim jest życie. Po latach w wierszu $W S z e-$ tejniach postać matki jawi się jak kontaminacja chrześcijańskiej Mądrości Bożej pomagającej oddzielić dobro od zła i pogańskiej bogini, Tellus Mater:

Ty jedna, mądra i sprawiedliwa, umiałabyś mnie uspokoić, thumacząc, że zrobiłem tyle, ile mogłem ${ }^{\mathrm{I}}$.

I tutaj utwór zamykają sakralizowane formuly: „pokój, pokój, / co skończone, to skończone" ${ }^{5}$. W utraconym rajskim „tam” przebywa matka, znów ukazana jako gwarantka ładu prowadzona przez ducha swojej ziemi, nauczycielka pisania i samego pisma, niezbędnego, by proroctwa dotyczące syna-poety mogły się spełnić. Dla mieszkańców okolicznych wiosek córka właściciela Szetejń jest autorytetem w dziedzinie wiedzy rolniczej, trochę Cererą, trochę Pomoną. Gdyby przywołać jej greckie imię, Demeter - okazałaby się, kim jest: uczestniczącą w symbolice Wielkich Bogiń władczynią, z którą, jak zapamiętało dziecko, liczą się wszyscy, wtajemniczoną i wtajemniczającą w misterium życia.

W książce Różewicza Matka odchodzi ${ }^{16}$ Stefania Różewiczowa - w wymiarze chrześcijańskiej z ducha pietas - ma także nieprzecięte związki z wsią i z ziemią. Jest równie mocno związana z ludową katolicką pobożnością - jawi się jako mała pokorna święta, uosobienie niewinności, wpisana w figurę Piety, pielgrzymująca do Częstochowy jak matka do matki ${ }^{17}$. To przede wszystkim opiekunka (co zapamiętali wszyscy komentatorzy), której wzrok zawsze towarzyszy synowi. Maryjność obu wizerunków - przy wszystkich różnicach - jest uderzająca. Ta pierwsza - Miłosza ma aspekt królowej, władczyni, tellurycznej bogini i nauczycielki mądrości. Posiadanie tak potężnej patronki wyposaża na całe życie. Ta druga - Różewicza - uczy pokory, prostoty, miłosierdzia i cierpienia, stając się w kulminacji dramatu macierzyństwa figurą Piety. Jest obrończynią i orędowniczką, która nigdy nie

I4 Idem, Wiersze, t. 5, Kraków 2009, s. 80.

15 Ibidem.

${ }^{16}$ Matka odchodzi, red. I. Iwasiów, J. Madejski, Szczecin 2002.

17 „Stefania Różewiczowa, uosobienie bezbronnego dobra, pracowitości, zaradności, oddania, nasuwa na myśl Marię, matkę Chrystusa” (G. Borkowska, op.cit., s. 109). 
opuści dziecka. U obu - niepodobnych przecież - Miłosza i Różewicza w tle jest symbolika sakralna i (mniej oczywista, ale niezbędna, by wypełnić archetypowy obraz) agrarna. Zagajewski (i jego matka) są reprezentantami miasta - czy będą to Gliwice, czy Lwów ze wspomnień poprzedniego pokolenia. Związek $\mathrm{z}$ ziemią i jej metaforyką został przerwany co najmniej w poprzedniej generacji. Widzenie kobiecości jest także oderwane od chtonicznych rytmów płodności. Ani idea władania, ani idea pokornej służby nie pasują do tego wizerunku.

Poetycki wiek XX ujmował obraz matki w sposób krańcowy - od sakralizacji do blasafemii. Tu wizerunek matki z jej słabościami i ograniczeniami sprawia, że jednostkowość zostaje ocalona. U Zagajewskiego obraz matki z wiersza jest zaprzeczeniem dwóch ważnych w XX-wiecznej literaturze stereotypów - tradycyjnego, sakralizowanego i (częstszego w prozie) wizerunku matki toksycznej, wzmocnionego przez psychologię, od naukowej (w różnych odmianach) do popularnej. Matka jest słaba, ale kochająca, niepozbawiona wad, ale z pewnością „wystarczająco dobra”. Gdyby sobie wyobrazić, że wiersz rozwija się w powieść (bo w esej wspomnieniowy już się rozwinął w Lekkiej przesadzie) powstałby bardzo wycieniowany wizerunek.

Matka z wiersza Zagajewskiego, podobnie jak nieomal wszyscy bohaterowie jego wierszy i esejów, nie ma związku z symboliką agrarną (jedyny wyjątek stanowi ciepło naszkicowana w Lekkiejprzesadziesylwetka jednej z sióstr ojca, która po wojnie zajmowała się w Gliwicach ogrodnictwem, jakby na potwierdzenie mojej tezy, ukazana jako osoba głęboko pobożna). To bardzo istotne, bo aczkolwiek nie należy opisywać świata wyobraźni żadnego poety poprzez to, czego w nim nie ma, ale to konsekwentne odcięcie rodzącej, dającej życie matki od porządku ziemi i płodnej natury jest tu podstawowym, chociaż nienazwanym źródłem jej słabości, kruchości, oderwania od aspektu macierzyństwa powiązanego bezpośrednio $\mathrm{z}$ materią. To on stanowił o sile, ale i grozie, związanych z życiem i śmiercią Wielkich Matek. Jedynie Herbert, wybierając atrybut dla bohaterki utworu Matka, wskazuje kłębek, sięgając tym samym po inną, równie archaiczną symbolikę, mającą swoje źródło w kobiecej pracy i twórczości. Nie może dziwić, że autor Apolla i Marsjasza nadaje anonimowej bohaterce cechy pokonanej Arachne i zarazem postarzałej, porzuconej Ariadny.

Upadł jej z kolan kłębek włóczki. Rozwijał się w pośpiechu i uciekał na oślep. Trzymała początek życia. Owijała na palec serdeczny jak pierścionek, chciała uchronić. Toczył się po ostrych pochyłościach, 
czasem piął się pod górę. Przychodził splątany i milczał. Nigdy już nie powróci na słodki tron jej kolan. Wyciągnięte ręce świecą w ciemności jak stare miasto ${ }^{\mathrm{I} 8}$.

U Herberta bezimienna matka pozostaje w miejscu, a syn, zgodnie z logiką opowieści o wyruszeniu w świat, oddala się od niej; jest też władczynią dzieciństwa porzuconą $w$ chwili dorastania. Co znamienne dla wyobraźni Herberta, zostaje ona porównana do opuszczonego miasta, miejsca stanowiącego symboliczne centrum świata. Matka w twórczości Zagajewskiego sama została wygnana $\mathrm{z}$ pełnego parków i ogrodów rodzinnego miasta, nie jest podobna do władającej nim Ateny ani do chtonicznej Demeter. Gdyby musiała mieć mitologiczny odpowiednik, byłaby chyba córką Cerery, oderwaną od swojej macierzystej rodziny, małą Persefoną błąkającą się w letniej sukience i wysłaną do „czarnego miasta” - Gliwic. Gdyby z kolei trzeba było dla niej wybrać archetypowy obraz zaczerpnięty z tradycji chrześcijańskiej, byłby to wizerunek Matki Boskiej z ucieczki do Egiptu. Maryja jest tu bezdomna, tułająca się ze swoją małą rodziną. Tak nakreślony wizerunek matki współuczestniczy w człowieczeństwie nomadycznym, nigdzie niezakorzenionym. Kobiecość nie jest tu określana poprzez odwołanie do miejsca, bohaterka nie może stać się „sobą dla siebie”, wciąż jest tylko kimś dla innych, nawet obcych. Nigdzie nie przynależy, nie ma swojej przestrzeni, a w tej, którą dla niej przeznaczono, nie czuje się u siebie. Wymiar symboliczny mówi nawet poprzez nieobecność. Archaiczne żywioły kobiecości: woda i ziemia, nie przychodzą na pomoc tak wykreowanej postaci. Poeta powietrza i ognia rzadko ukazuje właśnie te dwa kobiece żywioły. Gdy matka próbuje sięgać po ogień, po męski logos - zostaje ponownie odtrącona, jak w historii konkursu krasomówczego opisanego i w eseju Lekka przesada, i w niepublikowanym dotychczas wierszu. Jej światem nie może być także „kuchnia”, w tradycyjnym wyobrażeniu pisarzy-mężczyzn królestwo kobiety (by wspomnieć poemat Lucjana Szenwalda, który tak podobał się Miłoszowi, zatytułowany Kuchnia mojej matki).

Mówić o słabościach zmarłych, ukazywać ich w niepowtarzalnych, idiosynkratycznych cechach, to ocalać ich pamięć. Zagajewski zabiera głos po wielkich narracjach, wielkich buntach i wielkich złudzeniach. Postfreudowski rys wizerunku matki wiąże się także z tym, że nie ma tu mowy o „wyznaniu”. Na tle tego, co w literaturze wyznawano $\mathrm{w}$ minionym $\mathrm{XX}$ wieku, to, co

${ }^{18}$ Z. Herbert, Poezje, Warszawa 1998, s. 364. 
mówi Zagajewski, nie jest ani szokujące ani drastyczne, zgodnie z deklaracją zapisaną na wstępie autobiograficznego eseju Lekka przesada: „I tak wszystkiego nie opowiem” "9.

Możliwa jest zarówno „psychologiczna”, jak i „socjologiczna" interpretacja wiersza $O$ mojej matce, który pozwala przeniknąć do małej „kolonii profesorskiej” w Gliwicach. Utwór Zagajewskiego można by czytać z Dystynkcją Pierre'a Bourdieu w ręce jako opowieść o środowisku, jego zwyczajach i normach, jako „zwiniętą” narrację, jedynie potencjalnie dającą się rozwinąć, o środowisku, jego normach, obyczajach, o świecie wysiedlonych, w którym długo zmagano się z traumą. Jak o tym pisze Zagajewski w Lekkiej przesadzie: ,jakieś rytuały musiały zostać odprawione" ${ }^{20}$.

W dwudziestowiecznej literaturze polskiej Miłosz, Baczyński, Różewicz i wielu innych poetów-mężczyzn (jak wcześniej Mickiewicz i Słowacki) to „synowie matki”; Zagajewski na ich tle jawił się dotychczas jako syn ojca (a w Dwóch miastach - także wnuk dziadka ze strony ojca). Dla takiego wizerunku łatwiej znaleźć tradycję w poezji angielskiej i niemieckiej niż polskiej. $\mathrm{W}$ jednym $\mathrm{z}$ poetyckich autoportretów Zagajewskiego znalazły się słowa: „twarz ojca / włamuje się do jego twarzy” ${ }^{21}$. Teraz twarz matki wychodzi z cienia, również z cienia ojca. Strona ojca i strona matki da się pogodzić pod warunkiem podtrzymania antynomicznego myślenia. W eseju ukazana zostaje lakoniczność ojca, solidna rzetelna postawa przedstawiciela nauk ścisłych i (relatywna, tylko na tle tej rodziny) gadatliwość matki. Opisane zostają jej skrywane marzenia, jej trudne do ukrycia przed najbliższymi nieprzystosowanie do warunków, w jakich przyszło jej żyć. Jej głos, kiedyś nieuważnie słuchany, teraz wybrzmiewa.

Z eseju Lekka przesada wyłania się obraz matki zbudowany z pozornych sprzeczności. Ludwika Zagajewska była podobno wrażliwa i lękliwa, tymczasem zdobyła się na odwagę, gdy trzeba było ratować życie męża. Towarzyska i rozmowna, a równocześnie nieśmiała, jak analizuje po latach poeta, reprezentowała konglomerat cech wynikających z uwewnętrznionych przekonań i obawy deklasacji reprezentantki świata, który odszedł.

[...] nasza mała czteroosobowa rodzina: mama (obecna nawet jeśli nam nie towarzyszyła), próbująca zachować przedwojenne obyczaje, przekonana, że my jesteśmy „inni”, bo ojciec był „profesorem” ${ }^{22}$.

\footnotetext{
I9 A. Zagajewski, Lekka przesada, s. 5 .

${ }^{20}$ Ibidem, s. 159.

${ }^{21}$ Idem, Wiersze wybrane, s. 307.

${ }^{22}$ Ibidem, s. 44.
} 
[...] moja mama, która mimo swoich towarzyskich ambicji, mimo przekonania, że doskonale sobie radzi w każdym gronie, czy to rodzinnym, czy wśród nieznajomych, miała w sobie coś kruchego, tak jakby naprawdę nigdzie nie należała, nigdzie naprawdę nie potrafiła należeć, tylko grała swoją rolę, tak jakby jej ożywienie towarzyskie maskowało tylko lęk przed innymi, lęk przed nieznanym²3.

Historia matki, która w młodości brała udział w prawniczym konkursie krasomówczym, opowiedziana w eseju Lekka przesa$d a$, pozwala wysnuć jeszcze jedną interpretację. Wiersz Zagajewskiego jest przeciwieństwem mowy żałobnej, jest zaprzeczeniem klasycznej, dobrze skomponowanej mowy, której figury pochodzą z retoryki antycznej. Podobnie jak matka - Zagajewski, przegrywając, wygrywa, osiąga swój cel, porusza. Wiersz $O$ mojej matce to skondensowany, wycieniowany wizerunek, $\mathrm{z}$ którego wyłania się autoportret poety.

Nie znamy dobrze naszych rodziców, nie umiemy na nich patrzeć ani obiektywnie (cokolwiek by to miało znaczyć), ani krytycznie. To znaczy, owszem, potrafimy być wobec nich krytyczni, nawet bardzo, ale wtedy nie tyle ich widzimy, co wyobrażamy sobie ${ }^{24}$.

Zrozumienie, kim jesteśmy, przychodzi być może wtedy, gdy zaczynamy pojmować, że nie wiemy, jacy naprawdę byli nasi rodzice. Jak myślę, Rorty, jako syn poety, wiedział to bardzo dobrze. Zagajewski, syn profesora elektroniki, dla którego mowa poetycka stanowiła „lekką przesadę”, musiał odejść daleko od domu, by po latach móc do niego powrócić we wspomnieniu.

Granice naszego świata - by sparafrazować Ludwiga Wittgensteina - w dużej mierze, ale na szczęście nie w pełni, zależą od języka, jakim posługiwali się nasi rodzice. Poeta, ale także interpretator poezji, będzie mówił w granicach, które wprawdzie poszerzał przez lata lektur, ale które w najbardziej trwałych głębokich strukturach przyswoił, kiedy miał kilka lat. Słownik jego podstawowego języka odnajdziemy w metaforach, którymi się często posługuje i które chętnie powtarza. Jak podkreśla w swojej apologii poezji Rorty:

Kultury o bogatszych słownikach są bardziej w pełni ludzkie - bardziej dalekie od bestii - niż kultury o uboższych słownikach; pojedynczy mężczyźni i kobiety są bardziej w pełni ludzcy, kiedy ich pamięć jest obficie zapełniona wierszami ${ }^{25}$.

\footnotetext{
23 Ibidem, s. 50.

24 Idem, Lekka przesada, s. 464.

25 R. Rorty, op.cit., s. 47.
} 
"Ogrzewałem swe dłonie przy ogniu życia” ${ }^{26}$ - Rorty przywołuje Landora (czytywał go Stanisław Brzozowski, który - jak pamiętamy z Jechać do Lwowa - wywołał w tym mieście na początku XX wieku wielkie ożywienie swoimi wykładami). Filozofia i poezja mówią na różne sposoby, że ogień życia jest darem, a niepowtarzalne ludzkie życie jest tym bardziej godne tego, by je w pełni przeżyć, im bardziej niepewne, problematyczne czy niemożliwe stają się perspektywy eschatologiczne.

W posłowiu do antologii Powiedzieć to inaczej, w której znalazło się sporo zwłaszcza wczesnych wierszy Zagajewskiego, Michał Larek cytuje i komentuje Harolda Blooma. Te słowa chciałabym potraktować jako ważną wskazówkę:

„Świadomość jest dla poezji tym, czym marmur dla rzeźby: materiałem, który podlega obróbce”. A jeśli tak, to trzeba przyjąć , że „słowa są figurami świadomości.”. Tego rodzaju poezjopisanie będzie zatem według amerykańskiego badacza „jedynie prawdziwym sposobem poszerzania świadomości.” Bloom dodaje też: „sztuka czytania poezji jest ćwiczeniem, którego naturalnym efektem jest poszerzenie świadomości. Jest być może najbardziej autentycznym spośród zdrowych sposobów na osiągnięcie takiego celu" ${ }^{27}$.

Adam Zagajewski

\section{O mojej matce}

O mojej matce nie umiałbym nic powiedzieć jak powtarzała, będziesz kiedyś żałował, gdy mnie już nie będzie, i jak nie wierzyłem ani w ,już”, ani w „nie będzie”, jak lubiłem patrzeć, kiedy czytała modną powieść, zaglądając od razu do ostatniego rozdziału, jak w kuchni, uważając, że to nie jest dla niej odpowiednie miejsce, przyrządza niedzielną kawę, albo, jeszcze gorzej, filety z dorsza, jak czeka na przyjście gości i patrzy w lustro, robiąc tę minę, która skutecznie chroniła ją przed zobaczeniem siebie naprawdę (co, zdaje się,

26 Ibidem.

${ }_{27}$ M. Larek, Figury niepewności, w: Powiedzieć to inaczej. Polska liryka nowoczesna. Antologia, red. M. Larek, J. Borowczyk, Poznań 2011, s. 899. Cytaty z: H. Bloom, The Art. Of Reading Poetry (New York 2005, s. 55-56) krytyk przytacza w przekładzie Kacpra Bartczaka. 
odziedziczyłem po niej, jak i kilka innych słabości), jak potem swobodnie rozprawia o rzeczach, które nie były jej forte, i jak ja jej niemądrze dokuczałem, tak jak wtedy, kiedy ona porównała siebie do Beethovena, głuchnącego, a ja powiedziałem, okrutnie, ale wiesz, on miał talent, i jak wszystko mi wybaczała i jak ja to pamiętam, i jak leciałem z Houston na jej pogrzeb i jak nic nie umiałem powiedzieć, i wciąż nie umiem ${ }^{28}$.

\section{ANNA CZABANOWSKA-WRÓBEL}

\section{The Fire of Life.}

\section{Adam Zagajewski's poem “About My Mother”}

Any interpretation of one of the most personal poems written by Adam Zagajewski provides a good opportunity to reassess in the new light the elegiac, deeply personal body of his poetry, as well as the role of recollections and memory in the poet's poetical and essayist writing. The work is interpreted not only within the parental context of the literary output of the author of the essay Lekka przesada [A slight exaggeration] (2011), but also against the background of the important theme in Polish poetry, including modern poetry, i.e. the motif of the mother. The title for the present sketch has been drawn from the essay The Fire of Life, the apology of poetry authored by Richard Rorty, and stresses its unique role in expressing human experience, indicated by the American philosopher.

Key words: the poetry of Adam Zagajewski, remembrance in literature, elegy, the theme of the mother in Polish poetry, poetical self-portrait, the meaning of poetry according to Richard Rorty.

Anna Czabanowska-Wróbel - prof. dr hab. na Wydziale Polonistyki Uniwersytetu Jagiellońskiego. Zajmuje się historią literatury Młodej Polski i badaniami nad poezją współczesną. Autorka książek: Baśń w literaturze Młodej Polski (1996), Dziecko. Symbol i zagadnienie antropologiczne w literaturze Młodej Polski (2003), Poszukiwanie blasku. O poezji Adama Zagajewskiego (2005), Złotnik i śpiewak. Poezja Leopolda Staffa i Bolestawa Leśmiana w kręgu modernizmu (2009). Współredagowała tomy poświęcone poezji Tetmajera, Micińskiego, Bursy, Staffa, twórczości Wyspiańskiego i wyobraźni poetów pokolenia ‘68.

28 A. Zagajewski, Wiersze wybrane, Kraków 2010, s. 313 (wiersz niepublikowany we wcześniejszych tomach). 
